\title{
Öğretmen Adaylarının Matematik Öğretimine İlişkin Öz-Yeterlik, Matematiksel Problem Çözmeye Yönelik, Matematiksel İnançları ve Bu İnançlar Arasındaki İlişki*
}

\author{
Neslihan Usta $^{* *}$, Burçin Gökkurt Özdemir ${ }^{* *}$, Tamer Kutluca****
}

Makale Geliş Tarihi:30.09.2018

Makale Kabul Tarihi:25.12.2018

DOI: $10.35675 /$ befdergi. 465800

$\ddot{O} z$

Bu araştırmanın amacı, öğretmen adaylarının matematik öğretimine ilişkin öz-yeterlik, matematiksel problem çözmeye yönelik ve matematiksel inançlarının cinsiyet ve sinıf düzeyine göre incelenmesidir. Ayrıca, bu araştırmada, ögretmen adaylarının matematik ögretimine ilişkin öz-yeterlik, matematiksel problem çözmeye yönelik ve matematiksel inançları arasındaki ilişki incelenmiştir. Araştırma, tarama modeli kullanılarak yürütülmüştür. Araştırmanin örneklemini, Türkiye'nin üç farklı bölgesinde bulunan toplam 546 öğretmen adayı oluşturmaktadır. Çalışmada veri toplama aracı olarak belirlenen Matematik Öğretimi Öz-Yeterlik İnanç Ölçeği, Matematiksel Problem Çözmeye İlişkin İnanç Ölçeği ve Matematiksel İnanç Ölçeği aracılı̆̆ ile uygulamalar gerçekleştirilmiştir. Araştırmanın verileri de SPSS 20.0 paket programı kullanılarak analiz edilmiştir. Çalışma sonucunda ögretmen adaylarının cinsiyet değişkenine göre inançları arasında anlamlı bir farklılık bulunamamıştır. Sinıf düzeyi açısından incelendiğinde, matematiksel inançları arasında anlamlı bir farklılı̆̆ın olduğu ve bu farklılığın birinci ile üçüncü sınıflar arasında olduğu görülmüştür. Bu farklıllğın ise üçüncü sinıflar lehine olduğu görülmüştür. Sinıf düzeyine göre matematik öğretimi öz-yeterlik inançları ve matematiksel problem çözmeye yönelik inançları arasında ise anlamlı bir farklılık bulunamamıştır.

Anahtar Kelimeler: Matematiksel problem çözme inancl, matematiksel inanç, matematik ögretimi öz-yeterlik inancı, ögretmen adayl, matematik ögretimi.

\section{Prospective Teachers' Beliefs of Self-Efficacy Regarding Mathematics Teaching, Mathematical Problem Solving, Mathematical and the Relationship between These Beliefs}

\begin{abstract}
This research was to investigate the prospective teachers' beliefs of self-efficacy regarding mathematics teaching, their beliefs toward mathematical problem solving and

\footnotetext{
*Bu makale5-8 Mayıs 2016 tarihinde Çanakkale Onsekiz Mart Üniversitesi'nde düzenlenen 8. Uluslararası Eğitim Araştırmaları Kongresi’nde sözlü bildiri olarak sunulmuştur.

** Bartın Üniversitesi, Eğitim Fakültesi, Matematik ve Fen Bilimleri Eğitimi Bölümü, Bartın, Türkiye, nusta@bartin.edu.tr, bgokkurt@bartin.edu.tr, ORCID NO: 0000-0003-2662-1975, (iD) ORCID NO: 0000 000215510113

*** Dicle Üniversitesi, Ziya Gökalp Eğitim Fakültesi, Matematik ve Fen Bilimleri Eğitimi Bölümü, Diyarbakır, Türkiye, tkutluca@dicle.edu.tr, ORCID NO: 0000-0003-0730-5248 (iD)
}

Kaynak Gösterme: Usta, N., Gökkurt-Özdemir, B. ve Kutluca, T. (2019). Öğretmen adaylarının matematik öğretimine ilişkin öz-yeterlik, matematiksel problem çözmeye yönelik, matematiksel inançları ve bu inançlar arasındaki ilişki. Bayburt Eğitim Fakültesi Dergisi, 14(28), 347-371. https://doi.org/ 10.35675/befdergi.465800 
mathematics by their genders and grade levels. Also, in this research, it was investigated the relationship between prospective teachers' beliefs of self-efficacy regarding mathematics teaching, mathematical problem solving and mathematical. The research was carried out by employing a survey model. The sample of the research consisted a total of 546 prospective teachers residing in three different regions of Turkey. Data collection tools were Scale of Belief about Mathematics Teaching Self-Efficacy, Scale of Belief about Mathematical Problem Solving, and Scale of Belief about Mathematics. The data of the research were analyzed by using SPSS 20.0 package program. As a result of the study, there were not significant differences found between genders and beliefs of the prospective teachers. When the first and third graders were compared regarding the variable of grade level, there was a significant difference between their grade levels and mathematical beliefs, and the difference was in favor of the third. However, there were not found any significant differences between their grade levels and their beliefs of self-efficacy regarding mathematics teaching and their beliefs toward mathematical problem solving.

Keywords: Belief of mathematical problem solving, mathematical belief, mathematics teaching self-efficacy belief, prospective teacher, Mathematics teaching.

\section{Giriş}

Matematik eğitiminin temel hedeflerinden biri öğretim programlarında (Milli Eğitim Bakanlığı [MEB], 2017, 2018) belirtildiği gibi öğrencilerde akıl yürütme, iletişim kurma, ilişkilendirme ve problem çözme becerilerinin geliştirilmesidir. Eleştirel düşünebilen, yaratıcılıkları ve üst düzey düşünme becerileri gelişmiş bireyler toplumları bulundukları seviyeden daha üst seviyelere çıkarabilirler. Nitekim günümüzde problem çözme becerileri gelişmiş, sorun çözen ve yaratıcılığını kullanan bireylerin bulunduğu toplumların sanayi ve teknoloji başta olmak üzere her alanda lider oldukları aşikârdır. Yetenekli bireyler ancak yetenekli ve özellikleri olan öğretmenlerin rehberliğinde yetiştirilebilir. $\mathrm{Bu}$ nedenle, öğretmenlerin fakülte sıralarından itibaren mesleki yeterliklere sahip olarak yetiştirilmeleri ve diğer bir ifadeyle de konu alan bilgisiyle, genel kültürüyle ve öğretmenlik meslek bilgisiyle kendini sürekli yenileyen bireyler olmaları ilerlemenin bir anahtarı olarak görülmelidir (Yıldırım, 2008). Bazı araştırmacılar (Hofer ve Pintrich, 1997; Pajares, 1992) bireylerin inançlarının yaşamlarında aldıkları kararların, seçimlerin ve davranışların üzerinde önemli bir etkisi olduğu görüşünde birleşmektedirler. Deryakulu'na (2004) göre inançlar, “bireylerin yaşamlarında karşılaştıkları her durumu nasıl algıladıklarını, onlara ne tür anlamlar yüklediklerini ve nasıl davrandıklarını belirleyen, bireyler tarafından doğru olduğu varsayılan içsel kabuller ya da önermeler" olarak tanımlanmaktır. Bundan dolayı bireylerin inançları öğrenme ve öğretme süreçlerinde dikkate alınmalıdır (Akt. Eroğlu ve Güven, 2006). Dolayısıyla da öğretmenlerin kendilerine yönelik yeterlik algıları da öğretim etkinliklerini etkileyen faktörler arasındadır. Raymond (1998), ilkokul öğretmenlerinin inançlarının sınıf içi uygulamaları ile tutarlı olmadığını ve inançlar ile uygulamalar arasında yeni bir ilişki modelinin geliştirilmesinin gerekli olduğunu 
ifade etmiştir. Raymond'a göre, öğretmenlerin matematiğe olan inançları matematiğin öğretimine yönelik inançlarından daha etkilidir ve sınıf içi uygulamalarda çoğunlukla kendi deneyimlerinden etkilenerek uygulama yapmaktadirlar.

Öz-yeterlik inancı öğretim sürecini etkileyen önemli faktörlerden biridir. Özyeterlik "bireyin belli bir performansı göstermek için gerekli etkinlikleri organize ederek başarılı olarak yapma kapasitesi hakkında kendine ilişkin yargısı" dır (Bandura, 1997). Literatürde öz-yeterlik inancı ile akademik başarı, tutum ve motivasyon gibi çeşitli faktörlerin birlikte incelendiği çalışmalara (Ayotola ve Adedeji, 2009; Chen ve Zimmerman, 2007; Siegle ve McCoach, 2007; Usta ve Mirasyedioğlu, 2017; Yıldırım ve Yıldırım, 2015; Walsh, 2008; Zarch ve Kadıvar, 2006) rastlanılmaktadır. Bu çalışmalardan Yıldırım ve Yıldırım (2015) tarafından yapılan çalışmada, motivasyon, öz-yeterlik, kaygı ile matematik başarısı arasındaki ilişki üç farklı ülkede araştırılmıştır. Türkiye, Japonya ve Finlandiya'dan elde ettikleri bulgular sonucunda, her üç ülkede öz-yeterlik inancının matematik başarısı üzerinde pozitif bir etkisinin olduğunu göstermişlerdir. Ülkeler karşılaştırıldığında bu etkinin en çok Finlandiya'da olduğu tespit edilmiştir. Ayotolaa ve Adedeji (2009) ise, çalışmalarında ortaokul öğrencilerinin matematik öz-yeterlikleri ile cinsiyetleri arasındaki ilişkiyi incelemişlerdir. Çalışma sonucunda öğrencilerin matematik özyeterlik inançları ile cinsiyetleri arasında istatistiksel olarak anlamlı bir farklılık ortaya çıkmamıştır.

Öğretmen öz-yeterlik inancı ise, "öğretmenlerin öğrencilerine etkili bir eğitim ve öğretim verme konusunda kendilerine olan güven duygusu veya düşüncesi” dir (Guskey ve Passaro, 1994'ten Akt. Derman ve Özkan, 2007). İnsanların düşünce biçimlerini ve duygusal tepkilerini etkileyen öz-yeterlik inançları bireylerin yapacakları ile ilgili ne kadar çaba harcayacaklarına ve güçlükler karşısında neler yapabileceklerine ilişkin tahmin yürütmelerini sağlar (Schunk ve Hanson, 1985). Öğretmenlerin ve öğretmen adaylarının öz-yeterlik inançlarını çeşitli değişkenler açısından inceleyen çalışmalara literatürde rastlanmaktadır. Bunlardan bazıları sonuçları ile birlikte verilmiştir. Buna göre, yapılan bazı araştırmalar (Siegle ve McCoach, 2007) öz-yeterlik inançları ile akademik başarı ve kararlılık arasında pozitif yönde bir ilişki olduğunu göstermektedir. Siegle ve McCoach (2007) çalışmalarında öz-yeterlik konusunda eğitilmiş olan öğretmenlerin öğrencileri ile özyeterlik konusunda eğitilmemiş olan öğretmenlerin öğrencilerinin başarıları arasında anlamlı bir farkın olduğunu tespit etmişlerdir. Diğer bir çalışmada OrdonezFeliciano’ya (2009) göre, yapılandırmacı stratejiler ve öğretmen öz-yeterlik inançlarının bileşimi öğrenci başarısına çok önemli katkılar yapmaktadır. Buna göre öğretmen öz-yeterliği yüksek olan öğretmenler düşük olanlara göre ders anlatımlarında yapılandırmacı strateji, yöntem ve teknikleri daha fazla kullanmışlardır. Öğretmenlerin bu çabası da öğrencilerin başarılarına büyük oranda yansımıştır. Dede (2008), ilköğretim ve ortaöğretim matematik öğretmenleri ile yürüttüğü çalışmasında, öğretmenlerin öğretimlerine yönelik öz-yeterlik inançlarını 
incelemiş̧tir. Çalışma sonucunda, her iki kademede görev yapan öğretmenlerin, etkili matematik öğretimi yaptıklarına ve öğretimlerine ilişkin öz-yeterlik inançlarının, öğrencilerini matematik dersine motive etme ve öğrencilerine yardımcı olma konusundaki inançlarına kıyasla daha yüksek düzeyde olduğunu tespit etmiştir. Diğer taraftan, Terzi ve Mirasyedioğlu (2009) ise, ortaokul matematik öğretmeni adaylarının matematiğe yönelik öz-yeterlik algılarını, cinsiyet, akademik başarı, babanın eğitim düzeyi, mezun olunan lise gibi bazı değişkenler açısından incelemişlerdir. Çalışma sonucunda, öğretmen adaylarının akademik başarıları ile öz-yeterlik algıları arasında anlamlı bir farklılık bulunmuştur. Şahin, Gökkurt ve Soylu (2014) tarafından da öğretmen adaylarının ve öğretmenlerin matematik öğretimine ilişkin öz-yeterlik inanç düzeylerinin belirlenmesiyle yapılan karşılaştırmalı bir çalışmada, katılımcıların öz-yeterlik inanç düzeylerinin yüksek olduğu tespit edilmiş ancak gruplar arasında istatistiksel olarak anlamlı bir farklılık ortaya çıkmamıştır. Aksu (2008) tarafindan yapılan benzer bir çalışmada da sınıf, fen bilgisi ve okul öncesi öğretmen adaylarının matematik öğretimine ilişkin özyeterlik inançları cinsiyet ve anabilim dallarına göre incelenmiş ve gruplar arasında istatistiksel olarak anlamlı bir farklılık bulunamamıştır. Peker ve Erol (2018), matematik öğretmenlerinin öz-yeterlik inançlarını cinsiyet, kıdem ve çalıştıkları okul düzeyi gibi çeşitli değişkenler açısından incelemişlerdir. Çalışmada öğretmenlerin öz-yeterlik inançlarının yüksek düzeyde olduğu sonucu ile birlikte öğretmenlerin özyeterlik inançları ile cinsiyet ve kıdem arasında istatistiksel olarak anlamlı farklılık ortaya çıkarken çalıştıkları okul düzeyine göre anlamlı bir farklılık saptanmamıştır.

Öğretmenlerin matematiğe yönelik inançları ders sırasında aldıkları kararları etkilemektedir (Abrosse, Clement, Philipp ve Chauvot, 2004). Matematiğe yönelik inanç "bireyin matematiğe yönelik kavrayışları, değerleri, ideolojisi ve eğilimleridir". Matematik öğretmenlerinin matematiğe yönelik inançları, matematiğin doğasına yönelik inançlar, matematiği öğretmeyle ve matematiğin öğrenilmesiyle ilgili inançlar olmak üzere üç başlık altında ele alınmaktadır (Ernest, 1989). Buna göre, matematiğin ne işe yaradığı, niteliklerinin neler olduğu ile ilgili inançlar matematiğin doğası ile ilgili inançlardır. Matematik öğretiminin nasıl yapılacağı, amaçların ve öğretim programlarının nasıl belirleneceği ve öğretimde hangi strateji, yöntem ve tekniklerin kullanılacağı ile ilgili inançlar matematik öğretimiyle ilgili inançlardır. Öğretmenlerin matematiği nasıl gördüğü ve öğrencilerin öğrenirken zihinsel süreçlerinin nasıl işlediği ve öğrenmede ne tür etkinliklerin gerekli olduğu ile ilgili inançlar ise, matematiğin öğrenilmesine yönelik inançlardır. Bu bağlamda öğretmenlerin matematiğe yönelik inançları, öğrenmeöğretme süreçlerini ve sınıf içi etkinliklerini etkileyecektir (Philippou ve Christou, 1999). Çünkü matematiğin öğretiminde yeterli olduğunu düşünen matematik öğretmenlerinin matematiğe yönelik inançları öğretim davranışlarına yansıyacaktır (Dede, 2008). Dolayısıyla alanında donanımlı olmayan bir öğretmen, sınıfta güven verme ve saygıya dayalı bir otorite oluşturma konusunda güçlük çekecektir. $\mathrm{Bu}$ nedenle iyi yetişmiş matematik öğretmenlerinin öz-yeterlik inançlarının ve matematiğe yönelik inançlarının yüksek olması beklenmektedir (Dede, 2008). 
Literatürde öğretmenlerin ve öğretmen adaylarının matematiğe yönelik inançlarının çeşitli değişkenler açısından incelendiği çalışmalar bulunmaktadır. Örneğin, Sezgin-Memnun ve Katrancı (2012) tarafından yapılan çalışmada öğretmen adaylarının genel olarak matematiğe yönelik inançlarının olumlu olduğu ve cinsiyet açısından değerlendirildiğinde ise cinsiyet değişkenine göre inanç ortalama puanları arasında anlamlı bir farklılık olduğu saptanmıştır. Hacıömeroğlu (2013) matematik öğretmen adayları ile yaptığı çalışmasında, adayların matematik kaygısı ile matematiğe yönelik inançları arasındaki ilişkiyi incelemiştir. Buna göre matematik kaygısı yüksek olan adayların matematiğe yönelik inanç düzeylerinin düşük, matematik kaygısı düşük olan adayların ise matematiğe yönelik inanç düzeylerinin yüksek olduğunu ifade etmiştir. Ayrıca çalışmada sınıf düzeyine göre matematik kaygısı ile matematiğe yönelik inanç arasında anlamlı bir farklılık bulunmuştur. Fadlelmula, Çakıroğlu ve Sungur (2013) tarafından yapılan diğer bir çalışmada da matematik öğretmeni adaylarının matematiğe yönelik inançlarının cinsiyete göre farklılık gösterdiği ancak sınıf düzeyine göre anlamlı bir farklılığın bulunmadığı belirtilmiştir. Duatepe-Paksu (2008), öğretmenlerle yürüttüğü çalışmasında, öğretmenlerin matematik hakkındaki inançlarını belirleyerek bu inançları cinsiyet ve branş değişkenlerine göre incelemiş, öğretmenlerin matematiği kuralları ve işlemleri olan, ezberlenmesi gereken bir bilim olarak gördüklerini ortaya çıkarmıştır. Bununla birlikte çalışmada, matematik öğretmenlerinin inançlarının cinsiyete göre değişmediği ancak diğer branşa sahip öğretmenlere göre daha geleneksel bir yaklaşıma sahip oldukları görülmüştür.

Türkiye'nin farklı ülkelerle matematiksel inançlar yönünden karşılaştırıldığı çalışmalar (Aydın, 2014; Çakıroğlu, 2008) da bulunmaktadır. Çakıroğlu (2008), bir Türk üniversitesi ile bir Amerikan üniversitesini ilköğretim matematik öğretmeni adaylarının matematiksel inançları yönünden karşılaştırmıştır. Çalışmada Türkiye'deki öğretmen adaylarının, Amerika Birleşik Devletleri'ndeki öğretmen adaylarına göre matematiği öğretme konusunda daha güçlü bir inanca sahip oldukları belirtilirken, matematiği öğrenme konusunda benzer bir farklılığın bulunmadığı vurgulanmıştır. Benzer bir çalışma da Aydın (2014) tarafından yapılmıştır. Aydın, çalışmasında Türkiye, Almanya, Polonya, ABD, Singapur, Tayland ve Malezya'daki ilköğretim matematik öğretmeni adaylarını matematiksel inançlar yönünden karşılaştırmıştır. Buna göre, araştırmada Almanya ve Polonya'daki öğretmen adaylarının diğer ülkelere göre matematik hakkında daha olumlu inançlara sahip olduğu ve Türkiye'nin inançlar yönünden ABD ve Singapur gibi orta grupta bulunduğu belirtilmiştir. Araştırmada ayrıca matematik hakkındaki olumlu inançların matematik ve pedagojik matematik bilgileri üzerinde olumlu etki yaptığı, olumsuz inançların ise olumsuz etki yaptığı da ifade edilmiştir.

Öğrenme ve öğretme sürecinde etkili olan diğer bir unsur ise matematik öğretmenlerinin matematiksel problem çözmeye yönelik inançlarıdır. Öğrencilerin problem çözme sürecinde yaşadıkları deneyimler ve deneyimlerden çıkardıkları sonuçlar problem çözme becerilerinin gelişmesine katkı sağlamaktadır (Schoenfeld, 
1985). Problem çözme sürecinde öğrencinin düşünme biçimi, matematiksel kavramları nasıl anladığı, kavramlar arasındaki ilişkileri nasıl kurduğu ve çözüm önerileri ile ilgili net bilgiler ortaya çıkarılabilir (Chinnappan, 1998). Bu nedenle bu süreci yönetecek olan matematik öğretmenlerinin matematiksel problem çözmeye yönelik inançları önemlidir. Diğer bir ifadeyle öğrenme ve öğretme sürecinde matematik dersine yönelik inançlar öğrenmeyi ve problem çözmeyi etkilemektedir (Kloosterman ve Stage, 1992). Literatürde matematiksel problem çözmeye ilişkin inançların incelendiği araştırmalar olduğu görülmektedir. $\mathrm{Bu}$ araştırmalardan bazıları ilköğretim öğrencileri (Schommer-Aikins, Duell ve Hutter, 2005; TolukUçar, Pişkin, Akkaş ve Taşçı, 2010), matematik öğretmeni adayları (Baş, ÖzturanSağırlı ve Bekdemir, 2016; Çağırgan-Gülten ve Soytürk, 2012; Dede ve Karakuş, 2014; Fadlelmula, Çakıroğlu ve Sungur 2013; Hacıömeroğlu, 2013; Hart, 2002; Kayan, 2007; Kayan ve Çakıroğlu, 2008, 2013; Sezgin-Memnun, Hart ve Akkaya, 2012; Ünlü ve Sarpkaya-Aktaş, 2016; Yılmaz ve Delice, 2007) ve öğretmenler (Anderson, White, ve Sullivan, 2005) üzerinde yapılmıştır. Örneğin, Yılmaz ve Delice (2007) çalışmalarında matematik öğretmeni adaylarının problem çözme süreçlerini etkileyen inançlara sahip olduklarını ifade etmişlerdir. Buna göre bazı öğretmen adaylarının problemi kısa sürede çözemediğinde çözmekten vazgeçtiği ve yapamayacağına inandığı gözlemlenmiştir. Kayan ve Çakıroğlu (2008) tarafından yapılan diğer bir çalışmada ise öğretmen adaylarının bazılarının problem çözmeye yönelik inançlarının olumlu olmasına rağmen problemlerin çözümünde geleneksel bir bakış açısı sergileyerek daha önceden öğrendikleri adımları takip etmenin gerekliliğine inandıkları belirtilmiştir. Matematiksel problem çözmeye ilişkin inançların cinsiyete ve sınıf düzeyine göre incelendiği çalışmalar da bulunmaktadır. Örneğin, Çağırgan-Gülten ve Soytürk (2012), Kayan (2007) ve Sezgin-Memnun, Hart ve Akkaya (2012) tarafından öğretmeni adayları ile yapılan çalışmalarda öğretmen adaylarının matematiksel problem çözmeye yönelik inançları ile cinsiyetleri arasında anlamlı bir farklılık bulunmamıştır. Benzer şekilde ÇağırganGülten ve Soytürk (2012) öğretmen adaylarının matematiksel problem çözmeye yönelik inançlarının öğrenim görülen sınıf düzeylerine göre istatistiksel olarak anlamlı bir farklılık bulunmadığını ifade etmişlerdir. Baş, Özturan-Sağırlı ve Bekdemir (2016) tarafından yapılan çalışmada ise matematik öğretmeni adaylarının çoğunun problem çözmeye ilişkin inançları ile tutumlarının yüksek düzeyde olduğu belirlenmiştir.

Gelecekteki uygulamaların şekillendirilmesi ve matematik öğretiminin nasıl yapılacağ1 konusundaki belirleyici etkenlerin başında öğretmen adayının matematiğin doğasına, öğretimine ve öğrenilmesine yönelik inanc1, problem çözmeye yönelik inancı ve matematiği öğretebilme konusundaki kendine ilişkin değer yargısı olan öz-yeterlik inancı gelmektedir.

Günümüzde karşılaşılabilecek her türlü problemin üstesinden gelebilmek için kazanılması zorunlu hale gelen becerilerin başında ise problem çözme becerisi gelmektedir. Bu becerinin kazanılabilmesi için problem çözme süreçlerinin çok iyi 
bilinmesi, çözümlerin günlük yaşama uyarlanabilmesi diğer bir ifadeyle gerçek hayat problemlerinin matematiksel ortamda çözümlerinin bulunarak hayata uyarlanabilmesi ile mümkün olabilir. Bu bağlamda, okullarda öğrencilerin problem çözme becerisini kazanmalarında önemli rolü olan öğretmenlerin ve öğretmen adaylarının matematiksel problem çözmeye ilişkin inançları da önem kazanmaktadır. Çünkü öğretmen adaylarının sahip olduğu inançlar davranışlarına ve dolayısıyla sınıf içi etkinliklerine yansıyacaktır. Dolayısıyla, öğretmen adaylarının matematiğin doğasına, matematiğin öğretilmesine-öğrenilmesine ve zorlukların üstesinden gelebileceğine ilişkin algısının öğretim süreçlerinde önemli bir yere sahip olduğu buraya kadar yapılan araştırmaların 1şığında söylenebilir. Matematik öğretim sürecinde bu üç etkenin öğrenci başarısını önemli ölçüde etkilediği literatürde bulunan çalışmalar ile desteklenmektedir (Adnan ve Zakaria, 2010; Baş, ÖzturanSağırlı ve Bekdemir, 2016; Dede, 2008; Dede ve Karakuş, 2014; Duatepe-Paksu, 2008; Hacıömeroğlu, 2011, 2012 ve 2013; Hart, 2002; Kayan ve Çakıroğlu, 2008; Lloyd ve Wilson, 1998; Shahvarani ve Savizi, 2007). Ayrıca literatürde her üç inanç türünün birbirleri ile olan ilişki düzeylerinin incelendiği bir çalışmaya ulusal bazda rastlanılamamıştır. $\mathrm{Bu}$ nedenle, öğretmen adaylarının öğretim sürecini etkileyen matematik öz-yeterlik inançlarının, matematiksel problem çözmeye yönelik inançlarının ve matematiksel inançlarının öğretmen adaylarının cinsiyetine ve sınıf düzeyine göre bir anlamlı bir farklılık gösterip göstermediğinin incelenmesinin ve bu inançlar arasındaki ilişkinin düzeyinin belirlenmesininalan eğitimine katk1 sağlayacağı düşünülmektedir.

\section{Çalışmanın Amacı}

$\mathrm{Bu}$ çalışma ile öğretmen adaylarının matematik öğretimi öz-yeterlik inançlarının, matematiksel problem çözmeye yönelik inançlarının ve matematiksel inançlarının cinsiyet ve sınıf düzeyi değişkenlerine göre incelenmesi amaçlanmıştır. Ayrıca, bu çalışmada öğretmen adaylarının matematik öğretimi öz-yeterlik inançları, matematiksel problem çözmeye ilişkin inançları ve matematiksel inançları arasındaki ilişki ortaya konulmaktadır. Bu amaçla, aşağıda bu araştırmaya ilişkin araştırma problemlerine cevap aranmıştır.

1) Öğretmen adaylarının matematik öğretimi öz-yeterlik inançları, matematiksel problem çözmeye ilişkin inançları ve matematiksel inançları ne düzeydedir?

2) Öğretmen adaylarının matematik öğretimi öz-yeterlik inanç puanları, cinsiyete ve sinıf düzeyine göre anlamlı düzeyde farklılık göstermekte midir?

3) Öğretmen adaylarının matematiksel problem çözmeye yönelik inanç puanları, cinsiyete ve sınıf düzeyine göre anlamlı düzeyde farklılık göstermekte midir? 
4) Öğretmen adaylarının matematiksel inanç puanları, cinsiyete ve sınıf düzeyine anlamlı düzeyde farklılık göstermekte midir?

5) Öğretmen adaylarının matematik öğretimi öz-yeterlik inançları, matematiksel problem çözmeye ilişkin inançları ve matematiksel inançları arasındaki ilişki ne düzeydedir?

\section{Yöntem}

Bu bölümde, araştırmanın modeline, örneklemine, veri toplama araçlarına ve verilerin analizine yer verilmiştir.

\section{Araştırmanın Modeli}

Bu araştırma, tarama yöntemi kullanılarak yürütülmüştür. Tarama yöntemi, geçmişte ya da halen var olan bir durumu var olduğu şekliyle betimlemeye çalışmaktadır. Tarama modelinde araştırmalar genellikle çok fazla sayıda veriye dayalı olarak gerçekleştirildiğinden bu tür araştırmalar geniş örneklem ile yürütülür (Metin, 2014). $\mathrm{Bu}$ çalışmada öğretmen adaylarının matematik öğretimi öz-yeterlik inançlarının, matematiksel problem çözmeye yönelik inançlarının ve matematiksel inançlarının cinsiyet ile sınıf düzeyine göre incelenmesi amaçlandığından ve geniş örneklem ile yürütüldüğünden bu model esas alınmıştır. Ayrıca araştırmada bu inançlar arasındaki ilişkinin ortaya konması amaçlandığından ilişkisel tarama modeli kullanılmıştır.

\section{Örneklem}

Araştırmanın örneklemini, Türkiye'nin üç farklı bölgesinde bulunan Atatürk (293 aday), Dicle (104 aday) ve Bartın (149 aday) Üniversiteleri’nde öğrenim gören toplam 546 (420 kız, 126 erkek aday) matematik öğretmeni adayı oluşturmaktadır. $\mathrm{Bu}$ çalışmada ulaşılması kolay olduğundan kolay ulaşılabilir durum örneklemesi (Yıldırım ve Şimşek, 2008) yöntemi kullanılmıştır.

\section{Veri Toplama Araçları}

$\mathrm{Bu}$ çalışmadaöğretmen adaylarının matematik öğretimi öz-yeterlik inançlarını belirlemek için veri toplama aracı olarak; Hacıömeroğlu ve Şahin-Taşkın'ın (2010) Enochs, Smith ve Huinker'dan (2000) uyarladıkları Matematik Öğretimi ÖzYeterlik İnanç Ölçeği (MÖÖİÖ) kullanılmıştır. Ölçekte toplam 21 madde yer almaktadır. Bu ölçek, beşli likert tipinde olup, "Tamamen katılıyorum, Katılıyorum, Kararsızım, Katılmıyorum ve Hiç Katılmıyorum” şeklinde derecelendirilmiştir. Ölçek; kişisel yeterlik, etkili ögrretimde öğretmenin rolü ve öğretime ilişkin performans olmak üzere üç faktörlü bir yapıya sahiptir. Matematik öğretimi özyeterlik inanç ölçeği için Cronbach alfa güvenirlik katsayısı .71 olarak hesaplanmıştır. $\mathrm{Bu}$ çalışmada ölçek için hesaplanan Cronbach alfa güvenirlik katsayısı ise $.725^{\prime}$ dir. 
Öğretmen adaylarının matematiksel problem çözmeye yönelik inançlarını belirlemek için Haciömeroğlu'nun (2011), Kloosterman ve Stage'den (1992) uyarladıkları Matematiksel Problem Çözmeye İlişkin İnanç Ölçeği (MPÇİÖ) kullanılmıştır. Bu ölçek 24 maddeden oluşup, "Kesinlikle katılıyorum, Katılıyorum, Kararsızım, Katılmıyorum ve Kesinlikle Katılmıyorum" şeklinde beşli likert tipindedir. Ölçek, beş faktörlü bir yapıya sahiptir. Bu faktörler; matematiksel beceri, matematiğin yeri, problemi anlama, matematiğin önemi ve problem çözme becerisi'dir. Ölçek için hesaplanan Cronbach alfa güvenirlik katsayısı .768'dir. Bu çalışmada ölçeğin Cronbach alfa güvenirlik katsayısı .792 olarak hesaplanmıştır.

Öğretmen adaylarının matematiksel inançlarını belirlemek için Haciömeroğlu'nun (2012), Peterson, Fennema, Carpenter ve Loef'dan (1989) uyarladıkları Matematiksel İnanç Ölçeği (MIÖ) kullanılmıştır. Bu ölçek öğretmenlerin matematik inançlarını ortaya koymak amacıyla geliştirilmiştir. $\mathrm{Bu}$ araştırma kapsamında geliştirilen ölçek, öğrencilerin matematik bilgilerini oluşturmasına iliş̧kin inançlar, matematik kavramlarının öğretimine yönelik inançlar, öğretimin ögrrencilerin matematik gelişsimine göre düzenlenmesine iliş̧kin inançlar ve ögrencilerin matematik becerilerinin gelişimine ilişsin inançlar olmak üzere dört faktörden oluşmaktadır. Ölçeğin tümü için Cronbach alfa güvenirlik katsayısı 0.82'dir. Bu ölçek 34 maddeden oluşup, "Kesinlikle katılıyorum, Katılıyorum, Kararsızım, Katılmıyorum ve Kesinlikle Katılmıyorum" şeklinde beşli likert tipindedir. Kalaycı (2010)'ya göre Cronbach alfa güvenirlik katsayısı 0.60 ve 0.80 değerleri arasında bir değer ise ölçek oldukça güvenilirdir. Bu çalışmada da MIÖ için hesaplanan Cronbach alfa güvenirlik katsayısı .639 olarak hesaplanmıştır.

MÖÖIÖ’deki olumlu maddeler "tamamen katıllyorum" seçeneğinden itibaren 5, 4, 3, 2, 1 olarak puanlanırken, olumsuz maddeler ise ters yönde olacak şekilde 1, 2, $3,4,5$ şeklinde puanlanmıştır. MPÇïÖ ve MIÖ'deki olumlu maddeler "kesinlikle katıliyorum" seçeneğinden itibaren 5, 4, 3, 2, 1 şeklinde puanlanırken, olumsuz maddeler ters yönde olacak şekilde 1, 2, 3, 4, 5 şeklinde puanlanmıştır. Tablo 1'de bir öğrencinin ölçeklerden alabileceği maksimum ve minimum puanlar verilmiştir.

Tablo 1.

Ölçeklerden Alınabilecek Maksimum ve Minimum Puanlar

\begin{tabular}{cccc}
\hline Ölçekler & $\begin{array}{c}\text { Minimum } \\
\text { Puan }\end{array}$ & $\begin{array}{c}\text { Maksimum } \\
\text { Puan }\end{array}$ & $\begin{array}{c}\text { Ölçekteki } \\
\text { Madde Sayıs }\end{array}$ \\
\hline MPÇİÖ & 24 & 120 & 24 \\
\hline MÖÖIÖO & 21 & 105 & 21 \\
\hline MïÖ & 34 & 170 & 34
\end{tabular}

Tablo 1 incelendiğinde, bir öğrencinin matematiksel problem çözmeye ilişkin inanç ölçeğinden alabileceği minimum puan $(24 \times 1) 24$, maksimum puan $(24 \times 5) 120$, matematik öğretimi öz- yeterlik inanç ölçeğinden alabileceği minimum puan (21x1) 
21, maksimum puan $(21 \times 5) 105$ ve matematiksel inanç ölçeğinden alabileceği minimum puan (34x1) 34, maksimum puan (34x5) 170'tır. Bu çalışmada kullanılan ölçeklerin matematik öğretmen adayları için uygun olduğuna dair uzman görüşleri alınmıştır.

\section{Verilerin Analizi}

$\mathrm{Bu}$ çalışmadan elde edilen veriler SPSS 20.0 paket programı kullanılarak analiz edilmiştir. Veriler analiz edilirken .05 manidarlık düzeyi esas alınmışıtır. Verilerin analizinde, aritmetik ortalama, frekans, standart sapma gibi betimsel istatistikler ile bağımsız t-testi ve ANOVA gibi kestirimsel istatistikler yapılmıştır. Bunun için öncelikle verilerin normal dağılıma sahip olup olmadıklarına bakılarak bu amaçla Kolmogorov-Smirnov ve Shapirao Wilk testi $(\mathrm{p}>.05)$ yapılmıştır. Buna göre, verilerin sırasıyla çarpıklık ve basıklık değerleri: matematik öğretimi öz-yeterlik inancı için $0,151,-0,159$; matematiğe yönelik inanç için $0,115,-0,113$ ve problem çözmeye yönelik inanç için $-0,327,-0,477$ olarak bulunmuştur. Dolayısıyla verilerin normal dağılıma sahip oldukları görülmüştür. Varyansların eşitliği için ise Levene Testi yapılmış olup bu testin sonucuna göre, çalışmadan elde edilen verilerin varyanslarının eşit olduğu görülmüş̧ür $(\mathrm{p}>.05)$. Öğretmen adaylarının matematik özyeterlik, matematiksel problem çözmeye ilişkin ve matematiksel inançlarının arasında istatistiksel olarak anlamlı bir ilişkinin olup olmadığını tespit etmek amacıyla da korelasyon analizi yapılmıştır. Verilerin normal dağılıma sahip olup olmadığını belirlemek için çarpıklık-basıklık değerine bakılmış ve bu değerlerin -1 ve 1 arasında olduğu görüldüğünden Pearson Korelasyon Katsayısı hesaplanmıştır. Pearson korelasyon katsayısının 0.26 ile 0.49 değerleri arasında olması iki değişken arasında zayıf bir ilişkinin, 0.00 ile 0.25 değerleri arasında olması ise iki değişken arasında çok zayıf bir ilişkinin var olduğunu göstermektedir (Kalaycı, 2010).

\section{Bulgular ve Yorum}

$\mathrm{Bu}$ bölümde, öğretmen adaylarının matematik öğretimi öz-yeterlik inançlarının, matematiksel problem çözmeye yönelik inançlarının ve matematiksel inançlarının cinsiyet ve sınıf düzeyi değişkenlerine göre değişip değişmediğini belirlemek amacıyla yapılan analizler sonucunda elde edilen bulgulara yer verilmiştir. Ayrıca, matematik öğretimi öz-yeterlik inanç, matematiğe yönelik inanç ve matematiksel problem çözmeye yönelik inançölçeklerinden alınan puanlar arasındaki ilişkilere aitkorelasyon analizi sonuçlarına yer verilmiştir.

Öğretmen adaylarının matematik öğretimi öz-yeterlik inançlarının, matematiksel problem çözmeye yönelik inançları ve matematiksel inançlarının ne düzeyde olduğunun belirlenmesi için öğretmen adaylarının MÖÖIÖ, MPÇï̈ ve MIOÖ'den aldıkları puanlara ilişkin aritmetik ortalamaları ve standart sapmaları Tablo 2'de verilmişsir. 
Tablo 2.

Öğretmen Adaylarının MÖÖÏÖ, MPÇї̈ ve MïÖ'den Aldıkları Puanların Aritmetik Ortalamalart ve Standart Sapmalart

\begin{tabular}{ccccccc}
\hline Ölçekler & $\mathrm{N}$ & $\begin{array}{c}\text { Minimum } \\
\text { Puan }\end{array}$ & $\begin{array}{c}\text { Ölçek } \\
\text { Orta Puanı }\end{array}$ & $\begin{array}{c}\text { Maksimum } \\
\text { Puan }\end{array}$ & $\bar{x}$ & $\mathrm{~S}$ \\
\hline MÖÖİÖ & 546 & 21 & 63 & 105 & 80.90 & 6.860 \\
\hline MİÖ & 546 & 34 & 102 & 170 & 120.29 & 8.296 \\
\hline MPÇİÖ & 546 & 24 & 72 & 120 & 91.73 & 10.145
\end{tabular}

Tablo 2'de görüldüğü üzere, öğretmen adaylarının matematik öğretimi özyeterliğinden aldıkları puanların ortalaması 80.90'dır. MÖÖİ̈Ö orta puan puanı 63 $(3 \times 21)$ olduğu göz önüne alındığında, puan ortalamasının orta puanın üzerinde olmasından dolayı öğretmen adaylarının matematik öğretimi öz-yeterlik inançlarının yüksek olduğu söylenebilir.

Öğretmen adaylarının matematiksel inanç ölçeğinden aldıkları puanların ortalaması 120.29 ve ölçek orta puanı 102 (3x34)'dir. MiÖ’den aldıkları puanların ortalamasının, ölçek orta puanından fazla olduğu dikkate alındığında, öğretmen adaylarının matematiksel inançlarının yüksek olduğu söylenebilir. Yine Tablo 2 incelendiğinde, adayların MPÇiÖ'den aldıkları puan ortalamasının 91.73 ve ölçek orta puanın 72 (3x24) üzerinde olduğu görülmektedir. Bu sonuca dayalı olarak, öğretmen adaylarının matematiksel problem çözmeye ilişkin inançlarının yüksek düzeyde olduğu söylenebilir.

Öğretmen adaylarının cinsiyete göre matematiksel problem çözme, matematik öğretimi öz-yeterlik ve matematiğe yönelik inanç ölçeklerinden aldıkları puanlara ilişkin t-testi sonuçları da Tablo 3'te verilmektedir.

Tablo 3.

Öğretmen Adaylarının Cinsiyete GöreProblem Çözme, Öz-Yeterlik ve Matematiğe Yönelik İnanç Ölçeği Puanlarına İlişkin t-Testi Sonuçları

\begin{tabular}{|c|c|c|c|c|c|c|}
\hline & Cinsiyet & $\mathrm{N}$ & $\bar{X}$ & S & $\mathrm{Sd}$ & $\mathrm{t}$ \\
\hline \multirow{2}{*}{$\begin{array}{l}\text { Problem } \\
\text { Çözme }\end{array}$} & $\mathrm{K} 1 \mathrm{z}$ & 420 & 91.75 & 10.35 & \multirow[t]{2}{*}{544} & \multirow[t]{2}{*}{.098} \\
\hline & Erkek & 126 & 91.65 & 9.46 & & \\
\hline \multirow{2}{*}{ Öz-yeterlik } & $\mathrm{K} 1 \mathrm{Z}$ & 420 & 80.97 & 6.87 & \multirow[t]{2}{*}{544} & \multirow[t]{2}{*}{.471} \\
\hline & Erkek & 126 & 80.64 & 6.84 & & \\
\hline \multirow{2}{*}{$\begin{array}{l}\text { Matematiğe } \\
\text { Yönelik İnanç }\end{array}$} & Kiz & 420 & 120.43 & 8.34 & \multirow[t]{2}{*}{544} & \multirow[t]{2}{*}{.675} \\
\hline & Erkek & 126 & 119.86 & 8.15 & & \\
\hline
\end{tabular}

Tablo 3 incelendiğinde, öğretmen adaylarının matematiksel problem çözme

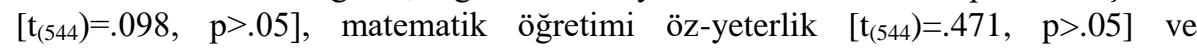


matematiğe yönelik inançları $\left[\mathrm{t}_{(544)}=.675, \mathrm{p}>\right.$.05] ile cinsiyet değişkeni arasında anlamlı bir farklılık olmadığ görülmektedir.

Aşağıda yer verilen Tablo 4'te ise, öğretmen adaylarının sınıf düzeyine göre matematiksel problem çözme, matematik öğretimi öz-yeterlik ve matematiksel inanç ölçeği puanlarına ilişkin ANOVA sonuçları yer almaktadır.

Tablo 4.

Öğretmen Adaylarının Sınıf Düzeyine Göre Problem Çözme, Öz-Yeterlik ve Matematiksel İnanç Ölçeği Puanlarına İlişkin ANOVA Sonuçları

\begin{tabular}{|c|c|c|c|c|c|c|}
\hline & $\begin{array}{l}\text { Varyansın } \\
\text { Kaynağ1 }\end{array}$ & $\begin{array}{l}\text { Kareler } \\
\text { Toplamı }\end{array}$ & $\mathrm{Sd}$ & $\begin{array}{c}\text { Kareler } \\
\text { Ortalamas1 }\end{array}$ & $\mathrm{F}$ & $\mathrm{p}$ \\
\hline \multirow{3}{*}{$\begin{array}{c}\text { Matematiksel } \\
\text { Problem } \\
\text { Çözme }\end{array}$} & Gruplararas1 & 309.165 & 3 & 103.055 & \multirow[t]{3}{*}{1.001} & \multirow[t]{3}{*}{.392} \\
\hline & Gruplariçi & 55778.717 & 542 & 102.913 & & \\
\hline & Toplam & 56087.883 & 545 & & & \\
\hline \multirow{3}{*}{$\begin{array}{l}\text { Matematik } \\
\text { Öğretimi } \\
\text { Öz-yeterlik }\end{array}$} & Gruplararası & 182.489 & 3 & 60.830 & \multirow[t]{3}{*}{1.295} & \multirow[t]{3}{*}{.275} \\
\hline & Gruplariçi & 25462.561 & 542 & 46.979 & & \\
\hline & Toplam & 25645.049 & 545 & & & \\
\hline \multirow{3}{*}{$\begin{array}{l}\text { Matematiğe } \\
\text { Yönelik } \\
\text { İnanç }\end{array}$} & Gruplararas1 & 805.964 & 3 & 268.655 & \multirow[t]{3}{*}{3.968} & \multirow[t]{3}{*}{.008} \\
\hline & Gruplariçi & 36699.561 & 542 & 67.711 & & \\
\hline & Toplam & 37505.526 & 545 & & & \\
\hline
\end{tabular}

Tablo 4 incelendiğinde, öğretmen adaylarının matematik öğretimi öz-yeterlik inançlarının sınıf düzeyine göre değişmediği görülmektedir $\left[\mathrm{F}_{(3,542)}=1.001, \mathrm{p}>\right.$.05]. Aynı şekilde Tablo 4'e göre öğretmen adaylarının matematiksel problem çözmeye yönelik inançları sınıf düzeyine göre anlamlı olarak değişmemektedir $\left[\mathrm{F}_{(3,542)}=1.295, \mathrm{p}>.05\right]$. Bununla birlikte yukarıdaki tablodan öğretmen adaylarının matematiğe yönelik inançlarının sınıf düzeyine göre anlamlı olarak değiştiği görülmektedir $\left[\mathrm{F}_{(3,542)}=3.968, \mathrm{p}<.05\right]$. Öğretmen adaylarının matematiğe yönelik inanç ölçeğinden aldıkları puanların hangi sınıf düzeyleri arasında olduğunu belirlemek için Scheffe Testi yapılmıştır. Test sonucunda, birinci $(\overline{\mathrm{X}}=118.67)$ ve üçüncü $(\bar{X}==122.15)$ sinıflar arasında anlamlı bir farkın olduğu ve bu farkın da üçüncü sınıfların lehine olduğu görülmüştür.

Tablo 5'te, öğretmen adaylarının matematik öğretimi öz-yeterlik, matematiksel problem çözmeye yönelik ve matematiksel inanç ölçeklerinden alınan puanlar arasındaki korelasyon analizi sonuçları yer almaktadır. 
Tablo 5 .

Öğretmen Adaylarının Matematik Öğretimi Öz-Yeterlik, Matematiksel Problem Çözmeye Yönelik ve Matematiksel Inanç Ölçeklerinden Alınan Puanlar Arasındaki Korelasyon Analizi Sonuçları

\begin{tabular}{cccc}
\hline Değişkenler & MPÇïÖ & MİÖ & MÖÖIÖÖ \\
\hline MPÇïÖ & 1 & & .365 \\
\hline MİÖ & .196 & 1 & .196 \\
\hline MÖÖÏÖ & & .311 & 1 \\
\hline
\end{tabular}

Öğretmen adaylarının MPÇiÖ’den aldıkları puanlar ile MÖÖİÖ’den aldıkları puanlar arasında istatistiksel olarak anlamlı bir ilişki olup olmadığını tespit etmek amaciyla yapılan korelasyon analizisonucunda $[\mathrm{r}(546)=.365 ; \mathrm{p}=<.05$ ] olarak bulunmuştur. Bu sonuca dayalı olarak, öğretmen adaylarının MPÇİÖ’den aldıkları puanlar ile MÖÖİÖ'den aldıkları puanları arasında pozitif yönde zayıf ve anlamlı bir ilişkinin olduğu anlaşılmaktadır.

Öğretmen adaylarının MiÖ’den aldıkları puanlar ile MÖÖİÖ'den aldıkları puanlar arasında istatistiksel olarak anlamlı bir ilişki olup olmadığını tespit etmek amaciyla yapilan korelasyon analizi sonucunda $[\mathrm{r}(546)=.311 ; \mathrm{p}=<.05]$ olarak bulunmuştur. $\mathrm{Bu}$ sonuca dayalı olarak, öğretmen adaylarının MïÖ'den aldıkları puanlar ile MÖÖİÖ’den aldıkları puanları arasında pozitif yönde zayıf ve anlamlı bir ilişkinin olduğu anlaşıllmaktadır.

Öğretmen adaylarının MPÇiÖ'den aldıkları puanlar ile MïÖ'den aldıkları puanlar arasında istatistiksel olarak anlamlı bir ilişki olup olmadığını tespit etmek amacıyla yapılan korelasyon analizi sonucunda $[\mathrm{r}(546)=.196 ; \mathrm{p}=<.05]$ olarak bulunmuştur. $\mathrm{Bu}$ sonuca dayalı olarak, öğretmen adaylarının MPÇi̇Ö’ den aldıkları puanlar ile MïÖ' den aldıkları puanları arasında çok zayıf ve anlamlı bir ilişki olduğu anlaşılmaktadır.

\section{Sonuç, Tartışma ve Öneriler}

$\mathrm{Bu}$ bölümde çalışmadan elde edilen bulguların değerlendirilmesiyle ortaya çıkan sonuçlara ve bu sonuçların literatürde bulunan bazı çalışmaların sonuçları ile tartışılmasına yer verilmektedir. Bu çalışmada öğretmen adaylarının matematik öğretimi öz-yeterlik inançlarının, matematiksel problem çözmeye yönelik ve matematiksel inançlarının cinsiyet ve sınıf düzeyine göre incelenmesi amaçlanmıştır. Buna göre öğretmen adaylarının cinsiyeti ve inançları arasında istatistiksel olarak anlamlı bir farklılık bulunamamıştır. Sınıf düzeyi açısından incelendiğinde ise matematik öğretmeni adaylarının sınıf düzeyleri ile matematiğe yönelik inançları arasında anlamlı bir farklılığın olduğu ve bu farklılığın da birinci ve üçüncü sınıflar arasında üçüncü sınıflar lehine olduğu görülmüştür. Ancak, sınıf düzeyi ile 
matematik öğretimi öz-yeterlik inancı ve matematiksel problem çözmeye yönelik inanç arasında anlamlı bir farklılık bulunamamıştır.

$\mathrm{Bu}$ çalışmanın ortaya çıkardığı sonuçlardan biri öğretmen adaylarının matematik öğretimi öz-yeterlik inanç düzeylerinin yüksek olduğudur. Öğretmenler ve öğretmen adayları üzerinde bu çalışmaya benzer karşılaştırmalı olarak yapılan bir çalışmada (Şahin, Gökkurt ve Soylu, 2014) her iki grubun matematik öğretimine yönelik özyeterliklerinin yüksek olduğu ancak istatistiksel olarak anlamlı bir farklılığın olmadığ 1 tespit edilmiştir. Bu çalışmayla ortaya konulan ortaokul matematik öğretmeni adaylarının matematik öğretimine yönelik öz-yeterlik inançlarının yüksek düzeyde olması sonucu ile Siegle ve McCoach (2007) ve Ordonez-Feliciano (2009) tarafından öğretmenler üzerinde yapılan çalışmaların sonuçları ile benzerlik gösterdiği söylenebilir. Öğretmenlerin öz-yeterlik inançlarının yüksek olması çalışmalarda (Ordonez-Feliciano, 2009; Siegle ve McCoach, 2007) belirtildiği gibi öğrenci başarısını ve kullanılan yöntem ve tekniklerin niteliğini artırmış dolayısıyla matematik öğretimine önemli katkılar sağlamıştır. Öğretimde “zor öğrenen, zor algılayan, motivasyonu olmayan veya motivasyonsuz öğrenciler de dâhil olmak üzere bütün öğrencilerin öğrenme süreçlerini etkileme kapasiteleri ile ilgili yargı" (Pajares ve Urdan, 2006) olarak tanımlanan öğretmen öz-yeterliğinin yüksek olması öğretmenlerin derste kullandıkları yöntem, teknik ve stratejileri, öğrencilerin matematiksel kavrayışlarını, matematiksel problem çözmeye ilişkin kendine güvenlerini ve yeni bilgileri uygulamaya ve öğrenmeye ilişkin tutumlarını etkilemektedir (Principles and Standards, 2000'ten Akt. Ordonez-Feliciano, 2009). $\mathrm{Bu}$ etkilerin olumlu yönde olduğuna ilişkin iki çalışmanın sonuçları yapılan bu çalışmanın sonuçlarını destekler nitelikte olduğundan burada paylaşılmaktadır. Buna göre, Siegle ve McCoach (2007) çalışmalarında öz-yeterlik konusunda eğitilmiş olan öğretmenlerin öğrencileri ile öz-yeterlik konusunda eğitilmemiş olan öğretmenlerin öğrencilerinin başarıları arasında anlamlı bir farklılığın olduğunu ortaya koymuşlardır. Benzer şekilde Ordonez-Feliciano’ya (2009) göre, yapılandırmacı stratejiler ve öğretmen öz-yeterlik inançlarının bileşimi öğrenci başarısına çok önemli katkılar yapmaktadır. Buna göre öğretmen öz-yeterliği yüksek olan öğretmenler öz-yeterliği düşük olan öğretmenlere göre ders anlatımlarında yapılandırmacı strateji, yöntem ve teknikleri daha fazla kullanmışlardır. Öğretmenlerin bu çabasının öğrencilerin başarılarına büyük oranda yansıdığı görülmüştür. Bu bağlamda matematik öğretmeni adaylarının matematik öğretimi için gerekli etkinlikleri organize ederek başarılı olarak yapma kapasitesi hakkındaki kendine ilişkin yargısının (Bandura, 1997) ve etkili bir eğitim ve öğretim yapma konusunda kendine olan güven duygusunun (Guskey ve Passaro, 1994, Akt. Derman ve Özkan, 2007) yüksek olmasının öğretimin kalitesini artırmada etkili olduğu, yapılan çalışmalar (Chen ve Zimmerman, 2007; Dede, 2008; Usta ve Mirasyedioğlu, 2017; Walsh, 2008; Yildırım ve Yildırım, 2015; Zarch ve Kadıvar, 2006) doğrultusunda söylenebilir. 
İkinci olarak bu çalışmada öğretmen adaylarının matematiğe yönelik inançlarının yüksek düzeyde olduğu sonucuna ulaşılmıştır. Benzer olarak matematik öğretmeni adaylarının matematiğe yönelik inançları üzerinde öğretmen eğitimi programlarının etkisinin incelendiği Dede ve Karakuş (2014) tarafindan yapılan bir çalışmada adayların birinci ve dördüncü sınıfta sahip oldukları inançlar (matematiğin doğasına yönelik inanç dışında) arasında istatistiksel olarak anlamlı bir farklılık bulunmuştur. Aynı çalışmada öğretmen adaylarının programdan mezun olurken sahip oldukları inanç puanlarına ait ortalamaların daha yüksek olduğu belirtilmiştir. Yapılan bu çalışmada da paralel olarak öğretmen adaylarının matematiğe yönelik inançları ile sınıf düzeyleri arasındaki farklılığın birinci ve üçüncü sınıflar arasında üçüncü sınıflar lehine olduğu görülmüştür. Dede'nin (2008) çalışmasının bir sonucu olarak ortaya koyduğu önemli bir tespit bu çalışmanın bu sonucunu destekler niteliktedir. Buna göre, matematik öğretiminde yetkin olduğunu düşünen bir matematik öğretmeninin inançları öğretime yansıyacağından alanında yetkin olmayan bir öğretmenin öğrencilere güven verme ve saygıya dayalı bir otorite oluşturma konusunda zorluklar yaşayacağını belirtmektedir. $\mathrm{Bu}$ nedenle öğretmenin hem matematiği öğretebileceğine ilişkin değer yargısının yani öz-yeterliğinin hem de matematiğe yönelik inançlarının yüksek olması beklenmektedir (Dede, 2008). Bu çalışmada da matematiğe yönelik inançlar sınıf düzeyinde incelendiğinde üçüncü sınıfların inanç düzeylerinin birinci sınıflara göre daha yüksek olduğu görülmüştür. $\mathrm{Bu}$ sonucun ortaya çıkmasında öğretmen adaylarının özel öğretim yöntemleri, okul deneyimi ve pedagojik alan bilgisini içeren dersleri ikinci ve üçüncü sınıftan itibaren almaya başlamış olmaları olabilir. Çünkü matematiğe yönelik inanç deyince literatürde de verildiği gibi matematiğin doğasına yönelik yani matematiğin ne olduğu ve ne işe yaradığı ile ilgili inançlar, matematik öğretiminin nasıl olacağ1, hangi yöntem ve tekniklerin kullanılacağı ve nasıl öğrenileceği gibi inançlar anlaşılmaktadır. Ayrıca üçüncü sınıfta öğrenim gören bir matematik öğretmeni adayı birinci sınıftan itibaren alan derslerinin büyük bir çoğunluğunu almış durumdadır. Bundan dolayı adayın matematiksel yapının anlaşılması bağlamında zihinsel bir olgunluğa erişmiş olabileceği de düşünülebilir. Bu çalışmanın sonucunu destekleyen bir çalışmada (Haser ve Doğan, 2012) özel öğretim yöntemleri derslerinin öğretmen adaylarının matematiğe yönelik inançlarını değiştirmede etkili olduğu belirtilmiştir (Akt. Dede ve Karakuş, 2014). Ancak Kayan vd. (2013) matematik öğretmeni adaylarının matematiğe yönelik inançları ile sınıf düzeyi arasında anlamlı bir farklılığın bulunmadığını belirtmişlerdir. Bu bağlamda iki çalışmanın sonuçlarının farklı olduğu görülmektedir.

$\mathrm{Bu}$ çalışmada ortaya çıkan diğer bir sonuç ise öğretmen adaylarının matematiksel problem çözmeye yönelik inançlarının yüksek düzeyde olduğudur. Baş, ÖzturanSağırlı ve Bekdemir (2016) ve Ünlü ve Sarpkaya-Aktaş (2016) tarafindan yapılan çalışmalarda ortaokul matematik öğretmeni adaylarının çoğunluğunun problem çözmeye yönelik inançlarının yüksek düzeyde olduğu sonucu ile bu çalışmanın sonucu paralellik göstermektedir. Ancak yapılan bazı çalışmalar (Duatepe-Paksu, 
2008; Kayan ve Çakıroğlu, 2008; Yılmaz ve Delice, 2007) ortaya koydukları farklı birtakım sonuçları ile dikkat çekmektedir. Buna göre bu çalışmalarda matematik öğretmeni adaylarının bazılarının problem çözme süreçlerini etkileyen matematiksel inançlara sahip oldukları ve geleneksel bir bakış açısıyla ezberlenmesi gereken ve kuralları olan bir disiplin olarak gördükleri matematĭgi ve matematik öğretimini değerlendirdikleri ayrıca kısa sürede çözüme ulaşamayacaklarını düşündüklerinde problemleri çözmekten vazgeçtiklerini ve yapamayacaklarına inandıkları belirtilmektedir.

Buraya kadar yapılan açıklamaları özetlemek gerekirse, bu çalışma ile ortaokul matematik öğretmeni adaylarının matematik öğretimi öz-yeterlik, matematiksel problem çözmeye yönelik ve matematiksel inanç düzeylerinin yüksek olduğu ortaya çıkmıştır. Sonuçlar matematik öğretmeni adaylarının matematik öğretimi özyeterliklerinin ve matematiğe yönelik inançlarının matematiksel problem çözmeye ilişkin inançlarına göre daha yüksek olduğunu göstermektedir. Matematik öğretmeni adaylarının matematiği etkili bir şekilde öğretebilmelerine yönelik inançları ve özyeterlikleri arasındaki derin ilişkiden (Swars vd., 2007) dolayı öğretmen adaylarının matematik öğretimine yönelik öz-yeterlik inançlarının yüksek düzeyde çıkmış olması istenilen bir durumdur (Dede, 2008). Diğer bir ifadeyle öğrenme ve öğretme sürecinde matematik dersine yönelik inançların öğrenmeyi ve problem çözmeyi etkilediği bilinen bir gerçektir (Kloosterman ve Stage, 1992). Bu çalışmanın bu bağlamda benzer sonuçlar ortaya koyduğu söylenebilir. Öğretmen adaylarının matematiksel problem çözmeye yönelik inanç düzeylerinin düşük çıkmasının bir nedeni problem çözme becerilerinin kazanılmasının zaman alması ve iletişim kurma, ilişkilendirme ve akıl yürütme olarak bilinen matematiksel süreç becerileri ile doğrudan ve derin bir ilişki içinde bulunmasından dolayı olabilir. Bu bağlamda öğretmen adaylarının inanç düzeylerinin arttırılmasında matematiksel süreç becerilerinin geliştirilmesine yönelik çalışmaların yapılması önerilebilir.

İlköğretim matematik öğretmeni adaylarının üç inanç türüne ait (matematik öğretimi öz-yeterlik inanç (MÖÖIÖ), matematiğe yönelik inanç (MIÖ) ve matematiksel problem çözmeye yönelik inanç (MPÇiÖ)) ölçeklerinden aldıkları puanlar arasındaki ilişkinin düzeyinin incelenmesi çalışmanın diğer bir boyutudur. Buna göre adayların MPÇiÖ' den aldıkları puanlar ile MÖÖiÖ' den aldıkları puanları arasında zayıf ve anlamlı, MïÖ' den aldıkları puanlar ile MÖÖIÖ' den aldıkları puanları arasında zayıf ve anlamlı ve MPÇiÖ' den aldıkları puanlar ile MIÖ' den aldıkları puanları arasında çok zayıf ve anlamlı bir ilişkinin olduğu görülmüş̧ür. Bu çalışmadan ortaya çıkan sonuçlarla birlikte akademik danışmanların öğretmen adaylarının öğrenme ve öğretme sürecindeki akademik başarılarını, motivasyonlarını ve performanslarını önemli ölçüde etkileyen (Bandura, 1997; Pajares, 1997; Schunk, 1991; Stresten Zeldin ve Pajares, Akt. Ayotolaa ve Adedeji, 2009) inançlarını dikkate almaları önerilebilir. Bu önerinin gerekçesi şu şekilde açıklanabilir. Bates, Latham ve Kim (2011) tarafindan yapılan çalışmada öğretmen adaylarının matematik öz-yeterlikleri ile matematik öğretimi etkinlikleri arasında 
pozitif bir ilişkinin var olduğu ve yüksek matematik öğretimi öz-yeterlik inancına sahip adayların matematiği öğretebileceklerini düşündükleri ancak öğrenciler üzerindeki etkisinin olup olamayacağından emin olamadıkları belirtilmiştir. $\mathrm{Bu}$ çalışmada da benzer olarak matematik öğretimi öz-yeterlik inancı ile matematiğe yönelik inanç arasında zayıf ve anlamlı bir ilişkinin olduğu görülmüştür. Bu iki çalışmanın sonuçları doğrultusunda matematiği öğretme konusunda kendine güvenen adayların yetiştirilmesi noktasında öğretim programlarında Okul Deneyimi, Öğretmenlik Uygulaması ve Özel Öğretim Yöntemleri gibi derslere daha fazla zamanın ayrılmasının öğretmen adayı-öğrenci etkileşimi için faydalı olacağı düşünülmektedir.

$\mathrm{Bu}$ çalışmada öğretmen adaylarının cinsiyet ve sınıf düzeyi değişkenlerine göre matematikselproblem çözme, matematik öğretimi öz-yeterlik ve matematiğe yönelik inançları arasında anlamlı farklılığın olup olmadığı ortaya konulmuştur. Buna göre, cinsiyet değişkeni açısından analiz edildiğinde matematik öğretimi öz-yeterlik, matematiğe yönelik ve matematiksel problem çözmeye yönelik inançlar ile cinsiyet değişkeni arasında istatistiksel olarak anlamlı bir farklılık bulunamamıştır. Bu sonuç Duatepe-Paksu'nun (2008) matematik öğretmeni adaylarının matematiğe yönelik inançlarının cinsiyete göre değişmediğini gösteren çalışmasının sonuçları ile paralellik göstermektedir. Ancak bu çalışmanın sonuçları ile farklılık gösteren Fadlelmula vd. (2013) tarafından matematik öğretmeni adayları ile yapılan çalışmada adayların matematiğe yönelik inançlarının cinsiyete göre anlamlı bir farklılık gösterdiği belirtilmektedir. Ayrıca bu çalışmanın sonuçlarına paralel olarak ilköğretim matematik öğretmeni adaylarının matematiksel problem çözmeye yönelik inançlarının cinsiyete göre anlamlı bir farklılığın bulunmadığını (Çağırgan-Gülten ve Soytürk, 2012; Kayan, 2007) gösteren çalışmalar bulunmaktadır. Bu çalışmanın sonucunun aksine ilköğretim matematik öğretmeni adaylarının matematiğe yönelik öz-yeterlik algılarının erkek adaylar lehine anlamlı bir farklılığın olduğu gösteren bir çalışma Terzi ve Mirasyedioğlu (2009) tarafından yapılmıştır. İkinci olarak buçalışmada sınıf düzeyi ile matematik öğretimi öz-yeterlik inancı ve matematiksel problem çözmeye yönelik inanç arasında anlamlı bir farklılık bulunmamıştır. Ancak matematik öğretmeni adaylarının sınıf düzeyleri ile matematiğe yönelik inançları arasında anlamlı bir farklılığın olduğu ve bu farklılığın da birinci ve üçüncü sınıflar arasında üçüncü sınıflar lehine olduğu görülmüştür. Dede'nin (2008) çalışmasının bir sonucu olarak ortaya koyduğu önemli bir tespit bu çalışmanın bu sonucunu destekler niteliktedir. Buna göre, matematik öğretiminde yetkin olduğunu düşünen bir matematik öğretmeninin inançları öğretime yansıyacağından alanında yetkin olmayan bir öğretmenin öğrencilere güven verme ve saygıya dayalı bir otorite oluşturma konusunda zorluklar yaşayacağını belirtmektedir. Bu nedenle öğretmenin hem matematiği öğretebileceğine ilişkin değer yargısının yani öz-yeterliğinin hem de matematiğe yönelik inançlarının yüksek olması beklenmektedir (Dede, 2008). Bu çalışmada da matematiğe yönelik inançlar sınıf düzeyinde incelendiğinde, üçüncü sınıfların inanç düzeylerinin birinci sınıflara göre daha yüksek olduğu görülmüştür. 
$\mathrm{Bu}$ sonucun ortaya çıkmasında öğretmen adaylarının Özel Öğretim Yöntemleri, Okul Deneyimi ve pedagojik alan bilgisini içeren dersleri ikinci ve üçüncü sınıftan itibaren almaya başlamış olmaları olabilir. Çünkü matematiğe yönelik inanç deyince literatürde de verildiği gibi matematiğin doğasına yönelik yani matematiğin ne olduğu ve ne işe yaradığı ile ilgili inançlar, matematik öğretiminin nasıl olacağ1, hangi yöntem ve tekniklerin kullanılacağı ve nasıl öğrenileceği gibi inançlar anlaşılmaktadır. Ayrıca üçüncü sınıfta öğrenim gören bir matematik öğretmeni adayı birinci sınıftan itibaren alan derslerinin büyük bir çoğunluğunu almış durumdadır. Bundan dolayı adayın matematiksel yapının anlaşılması bağlamında zihinsel bir olgunluğa erişmiş olabileceği de düşünülebilir. Bu çalışmanın sonucunu destekleyen bir çalışmada (Haser ve Doğan, 2012) Özel Öğretim Yöntemleri derslerinin öğretmen adaylarının matematiğe yönelik inançlarını değiştirmede etkili olduğu belirtilmiştir (Akt. Dede ve Karakuş, 2014). Ancak Kayan vd. (2013) matematik öğretmeni adaylarının matematiğe yönelik inançları ile sınıf düzeyi arasında anlamlı bir farklılığın bulunmadığını belirtmişlerdir. $\mathrm{Bu}$ bağlamda iki çalışmanın sonuçlarının farklı olduğu görülmektedir.

$\mathrm{Bu}$ araştırmada örneklem olarak kolay ulaşılabilir örneklem yöntemi seçilerek, araştırma üç üniversite ile yürütülmüştür. Benzer araştırma, Türkiye'deki diğer üniversitelerde öğrenim gören öğretmen adayları ile yürütülebilir. Böylece adayların gerek öz-yeterlik, gerekse matematiksel problem çözmeye yönelik ve matematiksel inançlarının düzeyleri belirlenerek öğretmen yetiştiren kurumların öğretim programlarını, adayların öz-yeterlik, matematiksel problem çözmeye ilişkin ve matematiksel inançlarını arttırmaya yönelik düzenlemeleri önerilmektedir. $\mathrm{Bu}$ alanda çalışma yapacak olan araştırmacılar, benzer araştırmayı matematik öğretmenleri ile yürüterek bu araştırmanın sonuçları ile karşılaştırabilirler.

\section{Kaynakça}

Abrosse, R., Clement, L., Philipp, R., \& Chauvot, J. (2004). Assessing prospective elementary school teachers' beliefs about mathematics and mathematics learning: Rationale and development of a constructed-response-format belief survey. School Scienceand Mathematics Journal, 104(2), 56-69.

Adnan, M. ve Zakaria, E. (2010). Exploring beliefs of pre-service mathematics teachers: A Malaysian perspective. Asian Social Science, 6(10), 152-159.

Anderson, J., White, P., \& Sullivan, P. (2005). Using a schematic model to represent influences on, and relationships between, teachers' problem-solving beliefs and practices. Mathematics Education Research Journal, 17(2), 9-38.

Aksu, H. H. (2008). Öğretmen adaylarının matematik öğretimine yönelik öz-yeterlik inançları. Abant İzzet Baysal Üniversitesi Ĕ̈itim Fakültesi Dergisi, 8(2), 161-170.

Aydın, S. (2014). Illköğretim matematik ögretmeni adaylarının öğretme bilgilerinin, inanışlarının ve öğrenme firsatlarının üniversiteler ve teds-m sonuçlarına göre 
karşılaş̧ırılması. Yayınlanmamış Doktora Tezi, Karadeniz Teknik Üniversitesi Eğitim Bilimleri Enstitüsü, Trabzon.

Ayotolaa, A. \& Adedejib, T. (2009). The relationship between mathematics self-efficacy and achievement in mathematics. Procedia Social and Behavioral Sciences I, 953-957.

Bandura, A. (1977). Self-efficacy: Toward a unifying theory of behavioral change, Psychological Review, 84(2), 191-215.

Bates, A. B., Latham, N., \& Kim, J. A. (2011). Linking preservice teachers' mathematics Self - Efficacy and mathematics teaching efficacy to their mathematical performance. School Science and Mathematics, 111(7), 325-333.

Baş, F., Özturan-Sağırlı, M. ve Bekdemir, M. (2016). The metacognıtıve awarenesses of preservice secondary school mathematics teachers, beliefs, attitudes on problem solving, and relationship between them. Journal of Theory and Practice in Education, 12(2), 464-482.

Chen, P. \& Zimmerman, B. (2007). A Cross-national comparison study on the accuracy of self-efficacy beliefs of middle-school mathematics students.The Journal of Experimental Education,75(3), 221-244.

Chinnappan, M. (1998). Schemas and mental models in geometry problem solving. Educational Studies in Mathematics, 36, 201-217.

Çağırgan-Gülten, D. ve Soytürk, İ. (2012). İlköğretim matematik öğretme adaylarının matematiksel problem çözme inançlarının bazı değişkenler açısından incelenmesi. The Journal of Academic Social Science Studies, 5(8), 641-656.

Çakıroğlu, E. (2008) The teaching efficacy beliefs of pre - service teachers in the USA and Turkey, Journal of Education for Teaching, 34(1), 33-44.

Dede, Y. (2008). Matematik öğretmenlerinin öğretimlerine yönelik öz-yeterlik inançları. Türk Ĕ̈itim Bilimleri Dergisi, 6(4), 741-757.

Dede, Y. ve Karakuş, F. (2014). Matematik öğretmeni adaylarının matematiğe yönelik inançları üzerinde öğretmen eğitimi programlarının etkisi. Kuram ve Uygulamada Eğitim Bilimleri, 14(2), 791-813.

Derman, A. ve Özkan, E. (2007). Kimya öğretmeni adaylarının öz-yeterlik algıları ve ögretmenlik mesleğine yönelik tutumlarının bazı değişkenler açısından incelenmesi. III. Uluslararası Öğretmen Yetiştirme Politikaları ve Sorunları Sempozyumu, Bakü: Azerbaycan Devlet Pedagoji Üniversitesi.

Duatepe-Paksu, A. (2008). Öğretmenlerin matematik hakkındaki inançlarının branş ve cinsiyet bakımından karşılaştırılması. Hacettepe Üniversitesi Eğitim Fakültesi Dergisi, 35, 87-97. 
Enochs, L. G., Smith, P. L., \& Huinker, D. (2000). Establishing factorial validity of the mathematics teaching efficacy beliefs instrument. School Science and Mathematics, $100(4), 194-202$

Ernest, P. (1989). The knowledge, beliefs and attitudes of the mathematics teacher: a model. Journal of Education for Teaching, 15(1), 13-33.

Eroğlu, S. E. ve Güven, K., (2006). Üniversite öğrencilerinin epistemolojik inançlarının bazı değişkenler açısından incelenmesi. Selçuk Üniversitesi Sosyal Bilimler Enstitüsü Dergisi, 16, 295-312.

Fadlelmula, F. K., Çakıroğlu, E., \& Sungur, S. (2013). Developing a structural model on the relationship amonf motivational beliefs, self-regulated learning strategies, and achievement in mathematics. International Journal of Science and Mathematics Education, 13(6), 1355-1375.

Hacıömeroğlu, G. (2011). Matematiksel problem çözmeye ilişkin inanç ölçeği'nin Türkçe'ye uyarlama çalışması. Dicle Üniversitesi Ziya Gökalp Eğitim Fakültesi Dergisi, 17, 119-132.

Hacıömeroğlu, G. (2012). Matematik İnanç Ölçeği'nin Türkçe’ye uyarlama çalışması. Çukurova Üniversitesi Sosyal Bilimler Enstitüsü Dergisi, 21(3), 175-184.

Haciömeroğlu, G. (2013). Mathematics anxiety and mathematics beliefs: What is the relationship in elementary pre-service teachers? Issues in the Undergraduate Mathematics Preparation of School Teachers, 5, 1-9.

Hacıömeroğlu, G. ve Taşkın, Ç. Ş. (2010). Sınıf öğretmeni adaylarının matematik öğretimi yeterlik inançları. Uludağ Üniversitesi Eğitim Fakültesi Dergisi, 23(2), 539-555.

Hofer, B. \& Pintrich, P. (1997). The development of epistemological theories: Beliefs about knowledge and knowing and their relationship to learning. Review of Educational Research, 67(1), 88-140.

Kalayc1, Ş. (2010). SPSS uygulamalı çok değişkenli istatistik teknikleri (5. Bask1). Ankara: Asil Yayın Dağıtım.

Kayan, F. (2007). A study on preservice elementary mathematics teachers' mathematical problem solving beliefs (Unpublished Master Thesis). Middle East Technical University, Ankara.

Kayan, F. ve Çakıroğlu, E. (2008). İlköğretim matematik öğretmen adaylarının matematiksel problem çözmeye yönelik inançları. Hacettepe Üniversitesi Eğitim FakültesiDergisi, $35,218-226$.

Kloosterman, P. \& Stage, K.F. (1992). Measuring beliefs about mathematical problem solving. School Science and Mathematics, 92(3), 109-115. 
Lloyd, G. \& Wilson, S. (1998). Supporting Innovation: The impact of a teacher's conceptions of functions on his implementations of a reform curriculum. Journal for Research in Mathematics Education, 29(3), 248-274.

Milli Eğitim Bakanlığı [MEB] (2017). Matematik dersi ögrretim programı (ilkokul ve ortaokul 1, 2, 3, 4, 5, 6, 7 ve 8. siniflar). Ankara: MEB Talim ve Terbiye Kurulu Başkanlığı.

Milli Eğitim Bakanlığ [MEB] (2018). Matematik dersi ögretim programı (ilkokul ve ortaokul 1, 2, 3, 4, 5, 6, 7 ve 8. sinıflar). Ankara: MEB Talim ve Terbiye Kurulu Başkanlığı.

Metin, M. (2014). Kuramdan uygulamaya bilimsel araştırma yöntemleri (1. Bask1). Ankara: Pegem Akademi.

Ordonez-Feliciano, J. (2009). Self-efficacy and instruction in mathematics. (Unpublished Doctoral Dissertation). Lynn University, Florida.

Pajares, M.F. (1992). Teacher's beliefs and educational research: Cleaning up a messy construct. Review of Educational Research, 62(3), 307-332.

Pajares, F. \& Urdan, T. C. (2006). Self-efficacy Beliefs of Adolescents, Greenwich, Conn: Unformation Age Publishing.

Peker, M. ve Erol, R. (2018). Investigation of the teacher self-efficacy beliefs of math teachers. Malaysian Onlıne Journal Of Educatıonal Scıences, 6(4), 1-11.

Peterson, P. L., Fennema, E., Carpenter, T., \& Loef, M. (1989). Teachers' pedagogical content beliefs in mathematics. Cognition and Instruction, 6(1), 1-40.

Philippou, G. \& Christou, C. (1999, September). Efficacy beliefs with respect to mathematics teaching. Paper presented at the Mathematical Beliefs and their Impact on Teaching and Learning of Mathematics Conference at Mathematisches Forschungsinstitut Oberwolfach, Germany.

Raymond, A. M. (1998). Inconsistency between a beginning elementary school teacher's mathematics beliefs and teaching practice, Journal for Research inMathematics Education, 28(5), 550- 576.

Schoenfeld, A. H. (1985). Mathematical problem solving. Orlando, FL: Academic Press.

Schommer-Aikins, M., Duell, O. K., \& Hutter, R. (2005). Epistemological beliefs, mathematical problem-solving beliefs, and academic performance of middle school students. The Elementary School Journal, 105(3), 289-304.

Schunk, D. H. \& Hanson, A. R. (1985). Peer models: Influence on children's self-efficacy and achievement.Journal of Educational Psychology, 77(3), 313-322. 
Sezgin-Memnun, D. ve Katranc1, Y. (2012). A research on the beliefs about mathematics learning and teacher efficacy of prospective teachers in Turkey. World Journal of Education 2(6), 66-78.

Shahvarani, A. \& Savizi, B. (2007). Analyzing some Iranian-high school teachers' beliefs on mathematics, mathematics learning and mathematics teaching. Journal of Environmental \& Science Education 2(2), 54-59.

Siegle, D. \& McCoach, D. (2007). Increasing student mathematics self-efficacy through teacher training. Journal of Advanced Academics, 18(2), 278-312.

Swars, S., Hart, L. C., Smith, S. Z., Smith, M. E., \& Tolar, T. A. (2007). Longitudinal study of elementary pre-service teachers' mathematics beliefs and content knowledge. Elementary Pre-Service Teachers' Mathematics, 107(9), 325-335.

Şahin, Ö., Gökkurt, B. ve Soylu, Y. (2014). Öğretmenlerin ve öğretmen adaylarının matematik öğretimi öz-yeterlik inançlarının karşılaştııılması. Dicle Üniversitesi Ziya Gökalp Ĕ̌itim Fakültesi Dergisi, 22, 120-133.

Terzi, M. ve Mirasyedioğlu, Ş. (2009). İlköğretim matematik öğretmen adaylarının matematiğe yönelik özyeterlik algılarının bazı değişkenler açısından incelenmesi. Tübav Bilim Dergisi, 2(2), 257-265.

Toluk-Uçar, Z., Pişkin, M., Akkaş, E. N. ve Taşçı, D. (2010). İlköğretim öğrencilerinin matematik, matematik öğretmenleri ve matematikçiler hakkındaki inançları. Eğitimve Bilim, 35(155), 131-144.

Usta, N. ve Mirasyedioğlu, Ş. (2017). Problem tabanlı öğrenme yaklaşımı ile matematik öğretiminin 7. sınıf öğrencilerinin matematik başarısına ve öz-yeterliğine etkisi. Kastamonu Ĕ̆itim Dergisi 25(6), 2263-2282.

Ünlü, M. ve Sarpkaya Aktaş, G. (2016). İlköğretim matematik öğretmen adaylarının problem kurma özyeterlik ve problem çözmeye yönelik inançları. Abant İzzet Baysal Üniversitesi Ĕ̈itim Fakültesi Dergisi, 16(4), 2040-2059.

Walsh, K. A. (2008). Relationship among mathematics anxiety, beliefs about mathematics, mathematics self-efficacy, and mathematics performance in associate degree nursing students. Nursing Education Perspectives. 29(4), 226-229.

Yıldırım, A. ve Şimşek, H. (2008). Sosyal bilimlerde nitel araştırma yöntemleri (6.Baskı). Ankara: Seçkin Yayıncılık.

Yıldırım, İ. (2008). Eğitim psikolojisi (1. baskl). Ankara: Anı Yayıncılık.

Yıldırım, S. ve Yıldırım, S. (2015). Öz-yeterlik, içe yönelik motivasyon, kaygı ve matematik başarısı: Türkiye, Japonya ve Finlandiya'dan bulgular. Necatibey Eğitim Fakültesi Elektronik Fen ve Matematik Eğitimi Dergisi, 5(1), 277-291. 
Yılmaz, K. ve Delice, A. (Eylül, 2007). Öğretmen adaylarının epistemolojik ve problem çözme inançlarının problem çözme sürecine etkisi. XVI. Ulusal EğitimBilimleri Kongresi'nde basılmış bildiri (ss. 575-581). Gaziosmanpaşa Üniversitesi, Tokat.

Zarch, M.K. \& Kadivar, P. (2006, May). The role of mathematics self-efficacy and mathematics ability in the structural model of mathematics performance,Proceedings of the 9th WSEAS International Conference on Applied Mathematics (pp. 242-249). İstanbul, Turkey.

\section{Extended Abstract}

Beliefs are defined as inherent admissions or suggestions that are presumed to be correct by individuals, which determine how individuals perceive any events, cases or objects that they encounter in their lives, what meanings they attribute to them and how they act against them. Accordingly, individuals' beliefs should be taken into account in the learning and teaching processes (Deryakulu, 2004 as cited in Eroğlu \& Güven, 2006)).Thus, teachers' perception of competence towards themselves is the main factor affecting the teaching activities. The most important determinant for the prospective teachers to shape the future practices and for the way they will use for the mathematics education, is the prospective teacher's belief for the nature, teaching and learning of mathematics; his/her belief for problem solving; and his/her self-efficacy belief that is his/her value judgement for teaching mathematics.

Beliefs of the prospective teachers will be reflected to them in-class activities. Therefore, it is thought that examining whether or not prospective teachers' selfefficacy beliefs in mathematics, their beliefs towards mathematics and also their beliefs towards mathematical problem solving show a significant difference according to gender and class level, and determining the level of correlation between these beliefs will contribute to field education. Moreover, there has not been a national study in the literature for the relationship of these three kinds of beliefs with each other.In this context, belief towards mathematics, belief towards self-efficacy and belief towards problem solving are as important as mathematics field knowledge learning in mathematics education. Because, in the mathematics teaching process, these three factors significantly affect student success. Many studies in the literature support this explanation (Adnan, \& Zakaria, 2010; Baş, Özturan-Sağırlı, \& Bekdemir, 2016; Dede, 2008; Dede \& Karakuş, 2014; Duatepe-Paksu, 2008; Hacıömeroğlu, 2011, 2012, 2013; Hart, 2002; Kayan \& Çakıroğlu, 2008; Lloyd \& Wilson, 1998; Shahvarani \& Savizi, 2007).

This research was carried out by a screening model. The screening model tries to describe a past situation or a present situation, in its existing form.In the screening model, researches are usually carried out with a large sample as it is based on a large number of data (Metin, 2014). The sample of the research consists of 546 (420 females, 126 males) prospective teachers who are studying at Atatürk (293), Dicle (104) and Bartın (149) Universities located in three distinct regions of Turkey in 
2014-2015 academic years. Data collection tools for determining the mathematics teaching self-efficacy of the prospective teachers are Belief Scale for Mathematics Teaching Self-Efficacy (BSMTSE) adapted from Enochs, Smith and Huinker(2000) by Hacıömeroğlu and Şahin-Taşkın (2010), Belief Scale for Mathematical Problem Solving (BSMPS) adapted from Kloosterman and Stage (1992) by Haciömeroğlu (2011) for determining the beliefs towards mathematical problem solving, and Mathematical Beliefs Scale (MBS) adapted from Peterson, Fennema, Carpenter and Loef (1989) by Haciömeroğlu (2012) for determining the mathematical beliefs. Data from this study were analyzed using SPSS 20 package program. Descriptive statistics such as arithmetic mean, frequency, standard deviation and predictive statistics such as independent t-test and ANOVA were used for data analysis.

One of the results of this study is that the level of the mathematics teaching selfefficacy beliefs of the prospective teachers is high. In a comparative study for teachers and prospective teachers performed similar to this study (Şahin, Gökkurt \& Soylu, 2014), it was found that the mathematics teaching self-efficacies of both groups were high, however there was no statistically significant difference.It can be said that the result of mathematics teaching self-efficacy beliefs of the prospective mathematics teachers being high was similar to the results of the studies performed on teachers by Siegle and McCoach (2007) and Ordonez-Feliciano (2009).

Secondly, in this study it was concluded that the prospective teachers' beliefs towards mathematics were high. Similarly, in a study performed by Dede and Karakuş (2014) in which the effect of teacher education programs on the prospective mathematics teachers' beliefs towards mathematics was investigated, a statistically significant difference was found between the beliefs (except for the belief for the nature of the mathematics) of the prospective teachers in first and fourth grades. In the same study, it was stated that the averages of the belief scores that the prospective teachers had when they graduated from the program were higher.

Another result of this study is that the prospective teachers' beliefs towards the mathematical problem solving are high. The result of the study performed by Baş, Özturan-Sağırlı and Bekdemir (2016) in which most of the prospective middle school mathematics teachers have had a high level of beliefs towards problem solving is parallel to the results of this study in which the prospective teachers' beliefs towards mathematical problem solving are high.

At the end of the study, there was found no significant difference between the genders and beliefs of the prospective teachers. From the perspective of class level, it was seen that there was a significant difference between the class level and beliefs towards the mathematics and this difference was in favor of third graders among the first and third graders. No significant difference was found between the class level, and mathematics teaching self-efficacy belief and the belief towards the mathematical problem solving. 
When the beliefs towards mathematics are examined at the class level, the result of the belief levels of the third graders being higher than the first graders may be arisen from the fact that the prospective teachers have begun to take lessons including special teaching methods, school experience and pedagogical field knowledge from the second and third grades.Because when it comes to beliefs towards mathematics, the beliefs towards the nature of the mathematics, i.e., beliefs as to what mathematics is and what it does, beliefs towards the way of mathematics teaching, beliefs towards the methods and techniques that will be used therefor, and beliefs towards the way of learning it, as indicated in the literature are understood. Furthermore, a prospective mathematics teacher who is studying in the third grade has taken a majority of field lessons from the first grade.It can therefore be assumed that the prospective teacher may have reached the mental maturity in the context of understanding the mathematical structure.In a study supporting the result of this study (Haser \& Doğan, 2012), it was stated that the lessons including the special education methods were effective in changing the beliefs of prospective teachers towards mathematics (as cited in Dede \& Karakuş, 2014).

Finally, in this study, the level of correlation between the scores of BSMTSE, BSMPS and MBS obtained by the prospective teachers was investigated. Accordingly, it was seen that there was a weak and significant correlation between the scores from BSMPS and the scores from BSMTSE; there was a weak and significant correlation between the scores from MBS and the scores from BSMTSE; and there was a quite weak and significant correlation between the scores from BSMPS and the scores from MBS. 